DOI:10.38136/jgon.703846

\title{
1-12 Aylık Bebeklerde Sık Karşılaşılan Ağrı Durumları ve Annelerin Bebeklerinin Ağrısına Yönelik Geleneksel Uygulamaları
}

\section{The Common Pain Conditions in 1-12 Month Infants and Traditional Practices of Mothers for Their Infants' Pain}

\author{
Gamze TESKERECi' \\ Aysun ÜNAL² \\ Derya EVGiN ${ }^{3}$ \\ Fatima ÜZÜM ${ }^{4}$ \\ Leyla KAMiK ${ }^{4}$ \\ Evin GEZME ${ }^{4}$ \\ Gülcan ÖNER ${ }^{4}$
}

(1) Orcid ID:0000-0003-0298-9716
(1) Orcid ID:0000-0001-5184-0008
(1) Orcid ID:0000-0002-3452-2937
(1) Orcid ID:0000-0003-4862-1909
(1) Orcid ID:0000-0002-5242-5628
(1) Orcid ID:0000-0003-0314-6489
(1) Orcid ID:0000-0002-5305-5166

${ }^{1}$ Akdeniz Üniversitesi Kumluca Sağlık Bilimleri Fakültesi, Doğum ve Kadın Hastalıkları Hemșireliği Anabilim Dalı, Antalya, Türkiye ${ }^{2}$ Akdeniz Üniversitesi Kumluca Sağlık Bilimleri Fakültesi, Yönetim Hemșireliği Anabilim Dalı, Antalya, Türkiye

${ }^{3}$ Akdeniz Üniversitesi Kumluca Sağlık Bilimleri Fakültesi, Çocuk Sağığı ve Hastalıkları Hemșireliği Anabilim Dalı, Antalya, Türkiye

${ }^{4}$ Akdeniz Üniversitesi Kumluca Sağllk Bilimleri Fakültesi, Hemșirelik Bölümü III. Sınıf Öğrencisi, Antalya, Türkiye

ÖZ

Amaç: Bu çalışma ile 1-12 aylık bebeklerde sık karşılan ağıı durumları ve annelerin bebeklerinin ağıı durumlarına yönelik geleneksel uygulamalarının belirlenmesi amaçlanmıştır.

Gereçler ve Yöntem: Kesitsel tipte olan bu araşıırmaya bir devlet hastanesinin çocuk polikliniğine herhangi bir nedenle başvuran 140 anne alınmıştır. Veriler araştırmacılar tarafından literatüre temellendirilerek hazırlanan soru formu ile toplanmışı̧ı. Çalışma sonucunda elde edilen veriler SPSS 22.0 programında ve tanımlayıcı istatistikler (yüzde, frekans ve ortalama) kullanılarak değerlendirilmiştir.

Bulgular: Annelerin yaş ortalaması $28.40 \pm 5.67$ ve $\% 28.6$ 'sı lise mezunudur. Bebeklerin yaş ortalaması $6.99 \pm 3.31$ ay ve $\% 52.1$ 'i erkektir. Bebeklerin \%81.4'ünün ağıı yaşadığı, en sık karşılaşılan ağrının \%67.1 ile karın ağrısı olduğu belirlenmiştir. Bebeklerinin ağrı durumunda annelerin \%71.4'ü doktora gitmenin yanı sıra, \%74.3'ü ağrıyı azaltmaya yönelik geleneksel bir uygulamaya başvurduğunu belirtmiştir. Bebeklerinin karın ağrısında anneler en sık karına masaj yapma (\%84.5), aşı ağrısında ağrı kesici ilaç verme (\%88.2), diş ağrısında ağıı kesici ilaç verme, boğaz ağrısında antibiyotik verme (\%63.6), göz ağrısında göze anne sütü damlatma (\%41.7) uygulamasına başvurduklar belirlenmiştir. Anneler evde kullandıkları tüm bu uygulamaların ağrıyı azaltmada etkisinin yüksek olduğunu belirtmişlerdir.

Sonuç: Annelerin bebeklerinin ağrı deneyiminde evde birçok geleneksel uygulamaya başvurdukları belirlenmiştir. Ailelerin akut ağıı yönetimi ile ilgili bilgilendirilmesi, kültürel yaklaşım, yanlış bilgi ve uygulamalara yönelmesini engellemektedir. Ailelerin bu konuda desteklenmesi önemlidir.

Anahtar Kelimeler: bebeklerde ağrı, geleneksel uygulamalar, hemşirelik

\section{ABSTRACT}

Aim: The aim of this study is to determine the frequent pain conditions in 1-12 months infants and the traditional practices of mothers for their infants' pain conditions.

Materials and Method: In this cross-sectional study, 140 mothers who applied to a children's hospital outpatient clinic for any reason were included. The data were collected through a questionnaire prepared by researchers based on the literature. The data obtained as a result of the study were evaluated in SPSS 22.0 program and using descriptive statistics (percentage, frequency and average).

Results: The average age of the mothers is $28.40 \pm 5.67$ and $28.6 \%$ are high school graduates. The average age of the infants is $6.99 \pm 3.31$ months and $52.1 \%$ are boys. It was determined that $81.4 \%$ of infants experienced pain, and the most common pain was abdominal pain with $67.1 \%$. In case of $71.4 \%$ of the mothers of infant pain as well as the doctor stated that apply to traditional practices for reducing the pain of $74.3 \%$. It was determined that the mothers applied the massage to the abdomen most frequently in abdominal pain $(84.5 \%)$, giving pain medication in vaccine pain $(88.2 \%)$, giving pain medication in toothache, giving antibiotics in sore throat $(63.6 \%)$, instillation of breast milk in the eye pain (41.7\%) of their infants. Mothers reported that a high effect in reducing pain of all these applications they use at home.

Conclusion: It was determined that mothers used many traditional practices at home in their infants' pain experience. Informing families about acute pain management prevents them from turning to cultural information, wrong information and practices. It is important to support families in this issue.

Key words: pain in infants, traditional practices, nursing 


\section{Gíriş}

Ağrı, insanları fiziksel, duygusal ve sosyal yönleri ile etkileyen korku, anksiyete ve depresyon gibi ciddi duygusal sorunları beraberinde getiren karmaşık ve çok boyutlu bir olgudur (1). Ağrı özellikle yenidoğan ve çocuklarda travma, hastalık ya da çeşitli tıbbi girişimlere bağlı en sık yaşanan deneyimlerden biridir

(1-7). Yenidoğan döneminde tekrarlanan ve tedavi edilmeyen ağrı deneyimi bebeğin fizyolojik, nöro-anatomik, bilişsel ve davranışsal gelişimini bozma potansiyeli vardır (4-10).

Tedavi edilmeyen ağrı, kısa süreli ve uzun süreli (dikkat eksikliği, görme-algılama bozukluğu gibi fizyolojik, davranışsal, bilişsel sekellere) komplikasyonlara yol açmaktadır (4,11-13). Diğer taraftan, gereksiz analjezik tedavisinin, mekanik ventilasyon intiyacının uzaması, beslemeyi geciktirmesi, beyin gelişiminin bozulması, zayıf sosyalleşme becerileri ve kısa süreli bellek görevlerinde performansın düşmesi gibi problemlere de yol açtığı belirtilmektedir. Bu nedenle yenidoğan ağrısının rutin değerlendirilmesi ve tedavisi önemlidir gelmiştir $(4,14,15)$. Bu bağlamda bebeklik döneminde yaşanan ağrı türlerinin belirlenmesi ve koruyucu önlemlerin alınması, uygun ve etkili farmakolojik ve non-farmakolojik yöntemlerle bebeğin ağrısının giderilmesi ve ailelere bu konuda eğitimlerin verilmesi, çocuk sağlığı ve gelişimi açısından önemli olduğu düşünülmektedir (16).

Ebeveynler çocuğun ağrısının değerlendirilmesinde ve yönetilmesinde önemli rol oynasa da (17-20), çocuğun ağrısını değerlendirebilmek ve gerekli müdahaleleri uygulamak için gerekli bilgi ve becerilere sahip olamayabilirler (21). Etkili ağrı yönetimine yönelik belirlenen engeller, ebeveynlerin bebeklerinin ağrılarını değerlendirmedeki zorluklarından, bilgi eksikliğinden ve kanıta dayalı ağrı yönetimine ilişkin önerilere ulaşmalarındaki güçlükten ve ağı kesici ilaçlarla ilgili problemlerinden kaynaklanmaktadır $(22,23)$. Ailelerin, çocuklarının ağrıları nedeniyle yaşadıkları kaygı ve endişe, sağılı kurumuna başvurmadan önce çocuklarının ağrısını azaltmak için bildikleri ya da duydukları çeşitli yöntemleri evde uygulamalarına neden olmaktadır.

Ülkemizde yürütülen çalışmalarda ailelerin çocuklarının ağrısına evde müdahale ettiklerini ve bu müdahalelerin bir kısmının hala geleneksel uygulamaları içerdiğini göstermektedir $(2,16,24-28)$ Özyazıcıoğlu ve Polat (2004)'ın çalışmasında annelerin \%63.2' sinin kulak ağrısını gidermek için çocuğu doktora götürdükleri, annelerin \%17.2'sinin birtakım geleneksel uygulamalara başvurdukları, annelerin \%11.5'inin kaderci bir yaklaşımla hiçbir şey yapmadıkları, annelerin \%8.1'inin de ağrı kesici ilaç verdikleri bulunmuştur (29). Çiftçi ve ark. (2017)'nın çalışmasında annelerin bebeklerinin karın ağrısına yönelik geleneksel uygulamalar arasında çeşitli zararlı uygulamalar (karnına veya ayakaltına alkol ve katran sürüldüğü, karabiber içirildiği gibi) kullandıkları belirlenmiştir (30).

Evde yapılan geleneksel uygulamalar ailelerin hastaneye başvurularını geciktirmektedir. Esenay ve ark. (2014)'nın çalışmasında ailelerin \%15.6'sı çocuklarının ağrısını gidermeye yönelik evde yaptıkları geleneksel uygulamalardan dolayı hastaneye başvurmada geciktiklerini düşünmektedir (2). Ailelerin akut ağrı yönetimi ile ilgili bilgilendirilmesi, kültürel yaklaşım, yanlış bilgi ve uygulamalara yönelmelerini engelleyecektir. Bu nedenle ailelerin bebeklerinin ağrı yönetimleri konusunda desteklenmeleri son derece önemlidir.

Bu çalışma ile 1-12 aylık bebeklerde sık karşılan ağıı durumları ve annelerin bebeklerinin ağrı durumlarına yönelik geleneksel uygulamalarının belirlenmesi amaçlanmıştır.

\section{GEREÇ VE YÖNETEM}

Kesitsel tipte olan bu araştırmaya, Ocak-Şubat aylarında Kumluca Devlet Hastanesi'nin çocuk polikliniğine herhangi bir nedenle başvuran ve araştırmaya katılmaya kabul eden 140 anne alınmıştır. Araştırma verileri, araşııımacılar tarafından literatüre temellendirilerek hazırlanan form $(2,16,24-29)$ yardımıyla, yüz yüze görüşme yöntemiyle toplanmıştır. Araştırmada kullanılan veri toplama formları iki bölümden oluşmaktadır. Birinci bölümde; annelerin ve bebeklerin sosyo-demografik özelliklerini belirlemeye yönelik sorular (bebeğin yaşı, cinsiyeti, anne-babanın yaşı, eğitimi, aile tipi, gelir düzeyi, yaşanan yer, çocuk sayısı, çocukta kronik hastalık varlığı, daha önce geçirilmiş ameliyat gibi) bulunmaktadır. İkinci bölümde ise; bebeklerde sık karşılaşılan ağrı durumları, ağrı belirtilerini farkında olmaya ilişkin annelerin farkındalık düzeyleri ve annelerin bebeklerinin ağrılarına yönelik geleneksel uygulamalarını belirlemeye yönelik sorular yer almaktadır.

\section{İstatistiksel Analizi}

Çalışma sonucunda elde edilen veriler SPSS 22.0 programında ve tanımlayıcı istatistikler (yüzde, frekans ve ortalama) kullanılarak değerlendirilmiştir.

\section{Etik Yönü}

Araştırmanın yapılabilmesi için Akdeniz Üniversitesi Tıp Fakültesi Klinik Araştırmalar Etik Kurulu'ndan (sayı:KAEK/28 ta- 
rih:08.01.2020) ve araştırmanın yapıldığı kurumdan izinler alınmıştır. Araştırma kapsamına alınan annelere araşırıma ile ilgili bilgi verilmiş, çalışmaya katılmaya davet edilmiş ve onamları alınmıştır.

\section{BULGULAR}

Araştırmaya katılan annelerin yaşları 18 ile 44 yaş arasında değişmekte olup, yaş ortalaması $28.40 \pm 5.67$ ve $\% 28.6$ 'sı lise mezunudur. Babaların yaşları ise 22 ile 60 yaş arasında değişmekte olup, yaş ortalaması $32.30 \pm 5.79$ ve $\% 36.4$ 'ü üniversite mezunudur. Ailelerin \%90.0'ının çekirdek aile olduğu, \%52.1'inin gelir durumunu giderine eşit olarak algıladığı, \%83.6'sı en uzun süre yaşadığı yerin ilçe olduğu bulunmuştur (Tablo 1). Ailelerin çocuk sayısı 1 ile 7 arasında değişmekte olup, ortalama çocuk sayısı $1.95 \pm 1.15$ 'dir.

Bebeklerin yaş ortalaması $6.99 \pm 3.31$ ay ve $\% 52.1$ 'i erkektir. Bebeklerin \%97.9'unda kronik bir hastalık bulunmamakta ve \%97.9'u daha önce herhangi bir cerrahi operasyon geçirmemiştir (Tablo 1).

Tablo 1. Ailelere ve bebeklerine ilişkin sosyodemografik özellikler

\begin{tabular}{|c|c|c|}
\hline Sosyodemografik özellikler & $\mathbf{n}$ & $\%$ \\
\hline \multicolumn{3}{|l|}{ Annenin eğitim durumu } \\
\hline Okuryazar değil & 8 & 5.7 \\
\hline İlkokul mezunu & 18 & 12.9 \\
\hline Ortaokul mezunu & 38 & 27.1 \\
\hline Lise mezunu & 40 & 28.6 \\
\hline Üniversite mezunu & 36 & 25.7 \\
\hline \multicolumn{3}{|l|}{ Babanın eğitim durumu } \\
\hline Okuryazar değil & 3 & 2.1 \\
\hline İlkokul mezunu & 11 & 7.9 \\
\hline Ortaokul mezunu & 30 & 21.4 \\
\hline Lise mezunu & 45 & 32.1 \\
\hline Üniversite mezunu & 51 & 36.4 \\
\hline \multicolumn{3}{|l|}{ Aile tipi } \\
\hline Çekirdek & 126 & 90.0 \\
\hline Geniş & 14 & 10.0 \\
\hline \multicolumn{3}{|l|}{ En uzun yaşanan yer } \\
\hline il & 5 & 3.6 \\
\hline İlçe & 117 & 83,6 \\
\hline Köy-mahalle & 18 & 12.9 \\
\hline \multicolumn{3}{|l|}{ Gelir durumu } \\
\hline Gelir giderden az & 52 & 37.1 \\
\hline Gelir gidere eşit & 73 & 52.1 \\
\hline Gelir giderden fazla & 15 & 10.7 \\
\hline \multicolumn{3}{|l|}{ Bebeğin cinsiyeti } \\
\hline Kiz & 67 & 47.9 \\
\hline Erkek & 73 & 52.1 \\
\hline \multicolumn{3}{|l|}{ Bebekte kronik hastalık varlığı } \\
\hline Kronik bir hastalık var & 3 & 2.1 \\
\hline Kronik bir hastalık yok & 137 & 97.9 \\
\hline \multicolumn{3}{|c|}{ Bebeğin cerrahi bir operasyon geçirme durumu } \\
\hline Cerrahi bir operasyon geçirmiş & 3 & 2.1 \\
\hline Cerrahi bir operasyon geçirmemiş & 137 & 97.9 \\
\hline
\end{tabular}

Bebeklerin ağrıyla karşılaşma durumları incelendiğinde; bebeklerin \%81.4'ünün ağrı yaşadığı, en sık karşılaşılan ağrının \%67.1 ile karın ağrısı olduğu belirlenmiştir. Bebeklerinin ağrı durumunda annelerin \%71.4'ü doktora gitmenin yanı sıra, \%74.3'ü ağrıyı azaltmaya yönelik evde geleneksel bir uygulamaya başvurduğunu belirtmiştir. Ayrıca annelerin \%69.3'ü bebeğinin ağrısıyla etkili şekilde baş edebildiğini belirtmiştir. Annelerin \%77.8'i ağrıyla baş edebilmeyle ilgili bilgiyi aile büyüklerinden aldığını ifade etmiştir (Tablo 2). Anneler bebeklerinin ağrısı olduğunu; bebeğinin ağlaması $(n=78)$, huzursuzlanması $(n=38)$, emmemesi $(n=25)$, uyumaması ( $n=19)$, ayaklarını karnına çekmesi $(n=12)$, ateşlenmesi ( $n=12)$, yüz ifadesi (yüzünü buruşturma, morarma, kızarma, nefes almada zorlanma) $(n=8)$, elini yumruk yaparak sıkması $(n=7)$, kendini kasması-sıkması-ıkınması $(n=4)$, ishal olması $(n=3)$, karnında şişlik-sertlik olması $(n=3)$, hareketlerinin artması ( $n=2)$, halsiz olması ( $n=2)$, ağrılı bölgeyi tutması $(n=2)$, annelik içgüdüsü ( $n=2)$, göz bebeklerinin küçülmesi $(n=1)$ 'nden anladıklarını bildirmiş̧erdir (Tablo 2).

Tablo 2. Bebeklerin ağrıyla karşılaşma durumları ve annelerin ağrıya yönelik tutum, yaklaşım ve algıları

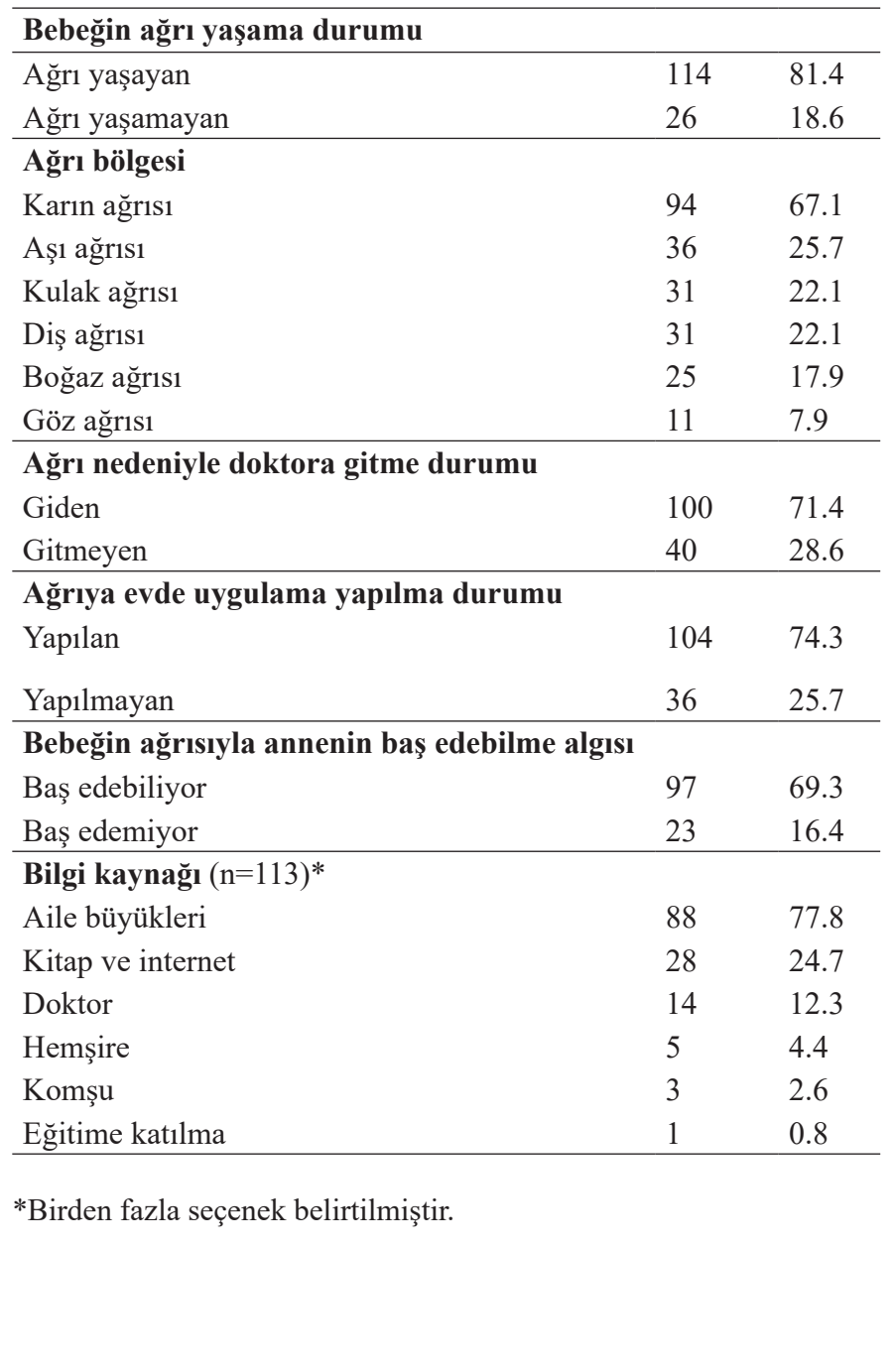


Bebeklerinin karın ağrısı olduğunda anneler; en sık bebeğin karnına masaj yapma (\%84.5), karnına yağ sürme (\%65.6), bebeğe bacak egzersizi yaptırma (\%58.3) ve ağrı kesici ilaç verme (\%27.1) uygulamalarına başvurduklarını belirtmişlerdir. Bebeklerinin karın ağrısını gidermek için, annelerin en sık kullandıkları yağların elma yağı $(n=47)$, zeytinyağı $(n=21)$, viks $(n=5)$, keki yağı $(n=2)$, defneyaprağı yağı $(n=1)$, bebe yağı $(n=1)$, badem yağı $(n=1)$, çörek otu yağı $(n=1)$ olduğu görülmüştür. Annelerin \%15.6'sı bebeklerinin karın ağrısını gidermek için bebeğine bitki çayı içirdiğini belirtmiştir. Bebeklere içirilen bitki çayları; rezene $(n=8)$, ada çayı $(n=3)$, papatya $(n=3)$, zencefil $(n=2)$, kimyon $(n=2)$, kekik $(n=1)$, nane-limon $(n=1)$ ve anne bebek çayı $(n=1)$ dır (Tablo 3).

Bebeklerinin aşı ağrısı olduğunda anneler en sık bebeğine ağrı kesici ilaç verme (\%88.2) ve ı ık duş aldırmayı (\%24.2) uyguladıklarını belirtmişlerdir.

Bebeklerinin kulak ağrısı olduğunda anneler en sık bebeğine ağrı kesici ilaç verme (\%46.9), bebeğinin kulağına anne sütü damlatma (\%46.4) ve kulağına masaj (\%21.9) uygulamalarına başvurduklarını bildirmişlerdir (Tablo 3).

Bebeklerinin diş ağrısı olduğunda anneler en sık; bebeğine ağrı kesici ilaç verme (\%50.0), bebeğinin diş etlerine yeşil soğan sürme $(\% 33.3)$ ve diş etlerine ağrı kesici jel sürme $(\% 25,0)$ uygulamalarına başvurduklarını belirtmişlerdir (Tablo 3).

Bebeklerinin boğaz ağrısı olduğunda anneler en sık bebeğine antibiyotik verme (\%63.6) ve bitki çayı içirme (\%36.4) uygulamalarına başvurduklarını belirtmişlerdir (Tablo 3).

Bebeklerinin göz ağrısı olduğunda anneler en sık bebeğin gözüne anne sütü damlatma (\%41.7), bebeğe ağrı kesici ilaç verme (\%33.3), emzirme (\%25.0) ve çay demi ile bebeğin gözüne pansuman yapma (\%25.0) uygulamalarına başvurdukları bildirmişlerdir. Anneler ağrıyı azaltmak için evde kullandıkları tüm bu geleneksel uygulamaların, bebeklerinin ağrılarını azaltmada etkisinin yüksek olduğunu belirtmişlerdir (\%83.3-100) (Tablo 3).
Tablo 3. Bebeklerinin karşılaştıkları ağrı türlerine göre annelerin uyguladıkları ağrıyı azaltmaya yönelik geleneksel yöntemler

\begin{tabular}{|c|c|c|c|c|c|}
\hline $\begin{array}{l}\text { Karına ağrısına yönelik evde yapılan } \\
\text { uygulamalar* }\end{array}$ & $\mathbf{n}$ & $\%$ & $\begin{array}{l}\text { Uygulamanın } \\
\text { etkisi }\end{array}$ & $\mathbf{n}$ & $\%$ \\
\hline Karına masaj uygulaması & 82 & 84.5 & Ağrıyı azalttı & 81 & 98.8 \\
\hline Yağ sürme & 63 & 65.6 & Ağrıyı azalttı & 62 & 98.4 \\
\hline Bacak egzersizi yaptırma & 56 & 58.3 & Ağrıyı azalttı & 56 & 100.0 \\
\hline Bebeği sallama & 31 & 32.3 & Ağrıyı azalttı & 30 & 96.8 \\
\hline Ağrı kesici ilaç verme & 26 & 27.1 & Ağrıyı azalttı & 26 & 100.0 \\
\hline Bitki çayı içirme & 15 & 15.6 & Ağrıyı azalttı & 15 & 100.0 \\
\hline Sicak uygulama & 14 & 14.6 & Ağrıyı azalttı & 13 & 92.9 \\
\hline $\begin{array}{l}\text { Diğer uygulama (gaz giderici damla içirme, } \\
\text { kuru kayısı yedirme, 1lı su içirme, adaçayı } \\
\text { yağı, çörekotu yağı, elma yağı, zeytinyağı } \\
\text { içirme, bezin altına soğan koyma, fitil yerine } \\
\text { sabun kullanma, viks sürme, bodur otu kay- } \\
\text { natıp sütle karıştırıp içirme) }\end{array}$ & 11 & 7.9 & Ağrıyı azalttı & 11 & 100.0 \\
\hline $\begin{array}{l}\text { Aşı ağrısına yönelik evde yapılan uygula- } \\
\text { malar* }\end{array}$ & $\mathbf{n}$ & $\%$ & $\begin{array}{l}\text { Uygulamanın } \\
\text { etkisi }\end{array}$ & $\mathbf{n}$ & $\%$ \\
\hline Ağrı kesici ilaç verme & 30 & 88.2 & Ağrıyı azalttı & 30 & 100.0 \\
\hline Ilık duş aldırma & 8 & 24.2 & Ağrıyı azalttı & 8 & 100.0 \\
\hline $\begin{array}{l}\text { Diğer uygulama (aşı yerine kolonya sürme, } \\
\text { ayakaltına viks sürme, ovma, masaj yapma, } \\
\text { emzirme, kucakta sallama) }\end{array}$ & 6 & 3.6 & Ağrıyı azalttı & 5 & 100.0 \\
\hline $\begin{array}{l}\text { Kulak ağrısına yönelik evde yapılan uygu- } \\
\text { lamalar* }\end{array}$ & $\mathbf{n}$ & $\%$ & $\begin{array}{l}\text { Uygulamanın } \\
\text { etkisi }\end{array}$ & $\mathbf{n}$ & $\%$ \\
\hline Ağrı kesici ilaç verme & 15 & 46.9 & Ağrıyı azalttı & 14 & 93.3 \\
\hline Kulağa anne sütü damlatma & 13 & 46.4 & Ağrıyı azalttı & 13 & 100.0 \\
\hline Kulağa masaj & 7 & 21.9 & Ağrıyı azalttı & 7 & 100.0 \\
\hline Yağ sürme (elma yağı, zeytinyağı) & 2 & 6.2 & Ağrıyı azalttı & 2 & 100.0 \\
\hline $\begin{array}{l}\text { Diğer uygulama (antibiyotik içirme, kırmızı } \\
\text { soğanı kaynatıp bebeğin kulağına damlatma, } \\
\text { tütünü kaynatıp kulağa damlatma ) }\end{array}$ & 4 & 2.9 & Ağrıyı azalttı & 4 & 100.0 \\
\hline $\begin{array}{l}\text { Diş ağrısına yönelik evde yapılan uygula- } \\
\text { malar* }\end{array}$ & $\mathbf{n}$ & $\%$ & $\begin{array}{l}\text { Uygulamanın } \\
\text { etkisi }\end{array}$ & $\mathbf{n}$ & $\%$ \\
\hline Ağrı kesici ilaç verme & 16 & 50.0 & Ağrıyı azalttı & 16 & 100.0 \\
\hline Diş etlerine yeşil soğan sürme & 9 & 33.3 & Ağrıyı azalttı & 9 & 100.0 \\
\hline Diş etlerine ağrı kesici jel sürme & 8 & 25.0 & Ağrıyı azalttı & 7 & 87.5 \\
\hline Diş kaşıyıcısı kullanma & 6 & 20.0 & Ağrıyı azalttı & 5 & 83.3 \\
\hline Diş etlerine masaj & 2 & 6.5 & Ağrıyı azalttı & 2 & 100.0 \\
\hline $\begin{array}{l}\text { Diğer uygulama (soğuk uygulama, dikkati } \\
\text { başka yöne çekme, diş etlerine elma yağı, } \\
\text { zeytin yağı sürme) }\end{array}$ & 4 & 2.9 & Ağrıyı azalttı & 4 & 100.0 \\
\hline $\begin{array}{l}\text { Boğaz ağrısına yönelik evde yapılan uygu- } \\
\text { lamalar* }\end{array}$ & $\mathbf{n}$ & $\%$ & $\begin{array}{l}\text { Uygulamanın } \\
\text { etkisi }\end{array}$ & $\mathbf{n}$ & $\%$ \\
\hline Antibiyotik verme & 14 & 63.6 & Ağrıyı azalttı & 14 & 100.0 \\
\hline $\begin{array}{l}\text { Bitki çay1 içirme (adaçayı, rezene, ıhlamur, } \\
\text { kekik-limon, nane-limon, papatya) }\end{array}$ & 8 & 36.4 & Ağrıyı azalttı & 8 & 100.0 \\
\hline $\begin{array}{l}\text { Diğer uygulama (ayva yaprağını kaynatıp } \\
\text { suyunu içirme, bebeğin sırtına hacamat uygu- } \\
\text { lama, llı su içirme, elmayı pişirip boğazına } \\
\text { sarma, boğazına eşarp bağlama, tehnel yağı } \\
\text { ile boğaza masaj yapma, zeytinyağı sürme, } \\
\text { pestili ısıtıp boğaza sarma) }\end{array}$ & 8 & 5.7 & Ağrıyı azalttı & 8 & 100.0 \\
\hline $\begin{array}{l}\text { Göz ağrısına yönelik evde yapılan uygula- } \\
\text { malar* }\end{array}$ & $\mathbf{n}$ & $\%$ & $\begin{array}{l}\text { Uygulamanın } \\
\text { etkisi }\end{array}$ & $\mathbf{n}$ & $\%$ \\
\hline Göze anne sütü damlatma & 5 & 41.7 & Ağrıyı azalttı & 5 & 100.0 \\
\hline Ağrı kesici ilaç verme & 4 & 33.3 & Ağrıyı azalttı & 4 & 100.0 \\
\hline Emzirme & 3 & 25.0 & Ağrıyı azalttı & 3 & 100.0 \\
\hline Çay demi ile göze pansuman yapma & 3 & 25.0 & Ağrıyı azalttı & 3 & 100.0 \\
\hline Göze masaj yapma & 1 & 0.7 & Ağrıyı azalttı & 1 & 100.0 \\
\hline
\end{tabular}

\section{TARTIŞMA}

Bebeklik döneminde deneyimlenen ağrı, bebeğin dış dünyaya uyumunu, anne bebek etkileşimini, duyuların gelişimini, büyümeyi ve ayrıca ileriki yaşlarda ağrıya karşı oluşturacağı yanıtları olumsuz yönde etkileyebilmektedir. Bu nedenle bebeklerde ağrı etkili girişimlerle geçirilemez ve iyi yönetilemezse birtakım fizyolojik, psikolojik ve davranışsal bozukluklara yol açabilmekte ve çocuk yaşamı boyunca bu bozukluklardan etkilenmeye devam edebilmektedir. $(20,31)$. Bu çalışma ile 1-12 aylık bebek- 
lerde sık karşılan ağrı durumları ve annelerin bebeklerinin ağrı durumlarına yönelik geleneksel uygulamalarının belirlenmesi amaçlanmıştır. Çalışmanın sonuçlarına göre; bebeklerin büyük çoğunluğunun ağrı deneyimlediği (\%81.4) ve en sık karın ağrısı yaşadıkları belirlenmiştir. Benzer nitelikte, Uğurlu ve arkadaşlarının (2014) çalışmasında bebeklerin \%86.2'sinin ağrıyla karşılaştıkları ve en sık görülen ağrının karın ağrısı (\%77.4) olduğu saptanmıştır (16). Bu çalışmada, bebeklerinin karın ağrısı olduğunda anneler en sık; bebeğinin karnına masaj yapma (\%84.5), karnına yağ sürme (\%65.6), bebeğe bacak egzersizi yaptırma (\%58.3) ve ağrı kesici ilaç verme (\%27.1) uygulamalarına başvurdukları bulunmuştur. Ayrıca anneler bebeklerinin karın ağrısın gidermek için en sık elma yağı ve zeytinyağı kullandığını belirtmiştir. Uğurlu ve ark. (2014)'larının çalışmasında da karın ağrısına yönelik en sık masaj uygulaması yapıldığı belirtilmiştir (16). Esenay ve ark. (2014)'larının çalışmasında ailelerin \%56.2'si karın ağrısı için evde geleneksel uygulamalardan herhangi birini yaptığı, en çok uygulanan geleneksel yöntemler sırasıyla masaj, sıcak uygulama, bitki çayları ve soğuk uygulamalar olduğu belirtilmiştir (2). Çalışkan ve Bayat (2011), annelerin \%84.7'sinin bebeklerinde gaz sancısı olduğunda gaz giderici damla verdiğini, \%1.9'unun bebeklerine bademyağı, zeytinyağı içirdiğini, \%10.3'ünün hiçbir şey yapmadığını belirlemiştir (25). Efe ve ark. (2013)'larının çalışmasına göre, annelerin \%29.2'sinin çocuklarının karın ağrısı problemlerinde, evde hazırladıkları karışımları çocukların karın ve ayak bölgelerine sürdükleri bulunmuştur (26). Belirtilen bu çalışmalarla birlikte araşııma bulgularımızın benzer olması sonucunda ülkemizde karın ağrısına yönelik bebek için zararlı olabilecek uygulamaların zaman içinde değişmeyen oranlarla yapılıyor olması, karın ağrısına yönelik girişimler konusunda ailelerin bilinçlendirilmesi gereksinimini ortaya koymaktadır. Özellikle de olası enfeksiyonlar, apandisit, ileus, volvulus gibi riskler açısından tehlikeli olabilecek bu uygulamaların yapılması için bir sağık profesyonelinden danışmanlık almaları konusunda bilgilendirilmeleri gerektiği düşünülmektedir.

Araştırma kapsamına alınan bebeklerde sıklık sırasına göre ikinci olarak aşı ağrısının görüldüğü (\%25.7) saptanmıştır. Bebeklerinin aşı ağrısı olduğunda anneler en sık; ağrı kesici ilaç verme (\%88.2) ve ılık duş aldırmayı (\%24.2) uyguladıklarını belirtmişlerdir. Uğurlu ve arkadaşlarının (2014) çalışmasında ise aşı ağrısı ile karşılaşan bebeklerin \%75.7'sine ağrı kesici ilaç verildiği belirlenmiştir (16).

Bebeklerin ağrı deneyimleri arasında kulak ağrısı en sık görülen üçüncü ağrı türüdür. Kulak ağrısı olduğunda anneler en sık; ağrı kesici ilaç verme (\%46.9), kulağa anne sütü damlatma (\%46.4) ve kulağa masaj (\%21.9) uygulamasına başvurduklarını bildirmiş̧erdir. Yapılan bir çalışmada çocuğun kulağı ağrıdığında ne yapılacağı sorusuna; annelerin \%40.3'ü bebeğin kulağına anne sütü, zeytinyağı, pırasa, soğan suyu damlatılacağını, \%17'si doktora götürüleceğini belirtmiştir (27). Bir başka çalışmada ise annelerin \%30.3'ünün çocukların ağrıyan kulağına anne sütü damlattıkları belirlenmiştir (26). Özyazıcıoğlu ve Polat (2004)'ın çalışmasında annelerin \%63.2' sinin kulak ağrısını gidermek için çocuğu doktora götürdükleri bulunmuştur (29). Bu çalışma ile uygun olarak ülkemizde yapılan diğer çalışmalarda da kulak ağrısı müdahalelerinde sakıncalı olabilecek uygulamaların devam ettiği ve konuya dikkat çekilmesi gerektiği düşünülmektedir.

Ağrı ile ilgili baş etme yöntemlerinin etkililiği konusunda annelerin düşünceleri değerlendirildiğinde annelerin yarıdan fazlası (\%69.3) bebeğinin ağrısıyla etkili baş edebildiğini belirtmişlerdir. Annelerin ağrıyla baş edebilmeyle ilgili bilgi kaynaklarının en çok aile büyükleri olduğu görülmektedir. Esenay ve ark. (2014)'nın çalışmasında ailelerin \%15.6'sı evde geleneksel uygulama yapmalarından dolayı hastaneye geciktiklerini düşünmektedir (2). Bu nedenle ağrıya yapılan geleneksel uygulamaların ailelerin hastaneye başvurularını geciktirmesi ve erken müdahale ile komplikasyonları önlenebilecek hastalık, ameliyat gibi durumları baskılaması açısından risk teşkil edebilmektedir. Ağrının yönetilmesinde önemli olabilecek adımlardan birisi de ağrının yorumlanması ve tanımlanmasıdır. Bu çalışmada anneler bebeklerinin ağrısı olduğunu; sıklıkla bebeğinin ağlaması, huzursuzlanması, emmemesi, uyumaması, ayaklarını karnına çekmesi, ateşlenmesi, yüz ifadesi (yüzünü buruşturma, morarma, kızarma, nefes almada zorlanma), elini yumruk yaparak sıkması, kendini kasması-sıkması-ıkınmasından anladıklarını bildirmişlerdir. Sağlık profesyonelleri tarafından kullanılan ağrı ölçeklerinde yer alan parametrelerle karşılaştırıldığında annelerin uygun değerlendirmeler yapabildikleri söylenebilir. Yenidoğanlarla sözel iletişim sağlanamamasından dolayı ağrının değerlendirilmesinde davranışsal ve fizyolojik değerlendirmeler esas alınmaktadır. Davranışsal değerlendirmeler; ağlama, yüz ifadeleri, solunum şekli, el ve bacak hareketleri ve uyanıklık ile yapııırken, fizyolojik değerlendirmeler; nabız, solunum, kan basıncı, vücut ısısı ve oksijen satürasyonu ile yapılır. Bunların içinde en belirgin yanıt ağlamadır $(4,32)$.

Ağrı, günümüzde hastayı sağık personellerinden yardım almaya yönelten en önemli sağlık sorunlarından biri olmasına karşın; ağrının giderilmesine yönelik alınan önlemlerin son derece 
yetersiz olduğu bilinmektedir. Etkili ağrı yönetimi için yenidoğanların yaşadığı ağrının doğru ve zamanında tanımlanması önemlidir. Yeni doğan ve bebeklerde ağrının yönetiminde hemşirenin etkin bir rol alabilmesi süreci, ağrının değerlendirilmesi, tedavisi, uygun girişimlerin seçilmesi ve bakımın planlanmasıyla başlar. Bundan yola çıkarak hemşire; bireyselleşmiş aile merkezli gelişimsel bakım vermeli, anne babanın olabildiğince bebeğin bakımında ve yapabilecekleri işlemlerde rol alabilmesini ve uygun zamanlı ve etkili famakolojik, nonfarmakolojik ağrı yönetimi stratejileri uygulanmasını sağlamalıdır $(1,4)$.

\section{Çalışmanın Sınırıııkları}

Çalışmanın sadece akdeniz bölgesinde yer alan bir ilçe devlet hastanesine başvuran kısıtı bir örneklem grubu ile yapılmış olması araştırmanın sınırlıı̆ııı oluşturmaktadır.

\section{SONUÇ}

Çalışma sonucunda; uygulanma sıklıkları değişse de annelerin bebeğin ağrısı olduğunda oldukça yüksek oranlarda geleneksel uygulamalara başvurdukları belirlenmiştir. Bu geleneksel uygulamaların bir kısmı mantıklı ya da mantık dışı, amaç ve sonuçları yönünden sağlığa yararlı ya da zedeleyici tutumlar olabilmektedir. Önemli bir sorunun habercisi de olabilen akut ağrının giderilmesi için yapılan geleneksel uygulamalar, teşhis ve tedaviyi geciktirerek çocuğun sağ ıı̆ını tehlikeye sokabilmektedir. Ailelerin akut ağrı yönetimi ile ilgili bilgilendirilmesi, kültürel yaklaşım, yanlış bilgi ve uygulamalara yönelmesinin önüne geçilebilmektedir. Bu nedenle hemşireler hizmet verdiği toplumun kültürel özelliklerini dikkate alarak, hastalık durumunda ve sağlığı devam ettirme sürecinde yapılan uygulamaları tespit edebilmelidirler. Yaşanılan bölgenin kültürel özellikleri dikkate alınarak geleneksel sağık uygulamalarının yarar ve zararları konusunda ailelerin farkındalığının artırıması ve desteklenmeleri önemlidir. Konu ile ilgili daha büyük örneklem üzerinde çaIışı|ması ve müdahale çalışmalarının yapıIması önerilmektedir.

\section{KAYNAKLAR}

1. Akcan $\mathrm{E}$, Polat $\mathrm{S}$. Yenidoğanlarda ağrı ve ağrı yönetiminde hemşirenin rolü. ACU Sağlık Bil Deg 2017;2:64-69.

2. Esenay FI, Çalık C, Doru Ö, Gülez Gedik G. Karın ağrısı ile hastaneye başvuran çocuklarda geleneksel uygulamalar. Mersin Univ Saglık Bilim Derg 2014;7:47-54.

3. Howard RF, Wiener S, Walker SM. Neuropathic pain in children. Archives of Disease in Childhood 2014, 99:84-89.

4. Ovalı F. Yenidoğanda Ağrının Önlenmesi, İçinde Temel Neonatoloji ve Hemşirelik İlkeleri (2.baskı), Dağoğlu T, Görak G (eds), Nobel Tip Kitabevleri, 2008: s. 695-702.

5. Robins PM, Smith SM, Glutting JJ, Bishop CT. A randomized controlled trial of a cognitive-behavioral family intervention for pediatric recurrent abdominal pain. J Pediatr Psychol 2005;30:397-408.
6. Shum S, Lim J, Page T, Lamb E, Gow J, Ansermino JM, Lauder $G$. An audit of pain management following pediatric day surgery at British Columbia Children's Hospital. Pain Res Manag 2012;17:328-334.

7. Stang AS, Hartling L, Fera C, Johnson D, Ali S. Quality indicators for the assessment and management of pain in the emergency department: a systematic review. Pain Res Manag 2014; 19:e179-190.

8. Schwaller F, Fitzgerald M. The consequences of pain in early life: Injuryinduced plasticity in developing pain pathways. European Journal of Neuroscience 2014;39:344-352.

9. Valeri BO, Holsti L, Linhares MBM. Neonatal pain and developmental outcomes in children born preterm: A systematic review. The Clinical Journal of Pain 2015;31:355-362.

10. Vinall J, Miller SP, Bjornson BH, Fitzpatrick KPV, Poskitt KJ, Brant $\mathrm{R}$ et al. Invasive procedures in preterm children: Brain and cognitive development at school age. Pediatrics 2014;133:412-442.

11. Brummelte S, Chau CM, Cepeda IL, Degenhardt A, Weinberg J, Synnes AR, et al. Cortisol levels in former preterm children at school age are predicted by neonatal procedural pain-related stress. Psychoneuroendocrinology 2015;51:151-63.

12. Mathew PJ, Mathew JL. Assessment and management of pain in infants. Postgraduate Medical Journal, Healt \& Medical Complete 2003;79:438-443.

13. Walker SM. Translational studies identify long-term impact of prior neonatal pain experience. Pain 2017;158:S29-S42.

14. Ferguson SA, Ward WL, Paule MG, Hall RW, Anand KJS. A pilot study of preemptive morphine analgesia in preterm neonates: effects on head circumference, social behavior, and response latencies in early childhood. Neurotoxicol Teratol 2012;34:47-55.

15. de Graaf J, van Lingen RA, Simons SHP, Anand KJS, Duivenvoorden HJ, , Weisglas-Kuperus $\mathrm{N}$, et al. Long-term effects of routine morphine infusion in mechanically ventilated neonates on childrens functioning: Five-year follow-up of a randomized controlled trial. Pain 2011;152:1391-1397.

16. Uğurlu E, Kalkım A, Sağkal T. 0-1 yaş arası bebeklerde sık karşılaşılan ağıı durumları ve ailelerin yaklaşımları. Fırat Tip Derg 2014;19:25-30.

17. DeMaso DR, Bujoreanu IS. Enhancing working relationship between parents and surgeons. Seminars in Pediatric Surgery 2013;22139-143.

18. Lim SH, Mackey S, Liam JL, He HG. An exploration of Singaporean parental experiences in managing school-aged children's postoperative pain: A descriptive qualitative approach. Journal of Clinical Nursing 2012;21:860-869. 
19. Ruiz M, Rivers N, Pop RS. Evaluating the effectiveness of the timing of postoperative education in the pediatric population. Journal of PeriAnesthesia Nursing 2012;27:10-17.

20. Fortier MA, Chou J, Maurer EL, Kain ZN. Acute to chronic postoperative pain in children: preliminary findings. Journal of Pediatric Surgery 2011;46:1700-1705.

21. Vincent C, Wilkie DJ, Szalacha L. Pediatric nurses' cognitive representations of children's pain. The Journal of Pain 2010;11: 854-863.

22. Fortier MA, Sender LS, Kain ZN. Management of pediatric oncology pain in the home setting: the next frontier.J Pediatr Hematol Oncol 2011;33(4):249-250.

23. Dorkham MC, Chalkiadis GA, von Ungern Sternberg $\mathrm{BS}$, Davidson AJ. Effective postoperative pain management in children after ambulatory surgery, with a focus on tonsillectomy: barriers and possible solutions. Paediatr Anaesth 2014;24:239248.

24. Vlieger AM, Blink M, Tromp E, Benninga MA. Use of complementary and alternative medicine by pediatric patients with functional and organic gastrointestinal diseases: results from a multicenter survey. Pediatrics 2008;122:446-451.

25. Çalışkan Z, Bayat M. Annelerin bebek bakımı uygulamaları ve etkileyen faktörler: Bir Kapadokya örneği. Anadolu Hemşirelik ve Sağlık Bilimleri Dergisi 2011,14:23-30.
26. Efe E, Öncel S, Yılmaz M. Kadınların diş, karın ve kulak ağrısı olan çocuklarına yaklaşımları. Ağrı 2013;24:69-76.

27. Rahman S, Altan S, Çam S, Yüksel H. Manisa ili Karaağaçlı beldesinde çocuk bakımına yönelik yöresel uygulamalar. Lokman Hekim Journal 2013;3:15-33.

28. Aşılar HR, Bekar P. 24 aylık çocuğu olan annelerin çocuk bakımına ilişkin bilgi, geleneksel inanç ve uygulamaları. JCP 2018;16:2:1-18.

29. Özyazıcıoğlu N, Polat S. 12 aylık çocuğu olan annelerin bazı sağlık sorunlarında başvurdukları geleneksel uygulamalar. Atatürk Üniv. Hemşirelik Yüksekokulu Dergisi 2004;7:3038.

30. Çiftçi EK, Kahraman S, Aydın D. Türkiye'nin iki farklı bölgesindeki 1-12 aylık bebeği olan annelerin karın ağrısına yönelik geleneksel uygulamalarının belirlenmesi. HSP 2017;4:8087.

31. Taddio A, Shah V, Gilbert-MacLeod C, Katz J Conditioning and hyperalgesia in newborns exposed to repeated heel lances. Journal of American Medical Association 2002;288:857-861.

32. Plaja F, Alesi M. Pain in newborns and children. Prof Inferm 2004:57:135-138. 